http://journal.uinsgd.ac.id/index.php/biodjati

\title{
GROWTH RATE AND CAPSAICIN LEVEL OF \\ CURLY RED CHILI (Capsicum annum L.) ON BIOFERTILIZER AND BIOGAS SLUDGE APPLICATION
}

\author{
Dwi Umi Siswanti*1, Melinda Fajar Lestari²
}

Received : February 17, 2019

Accepted : April 18, 2019

DOI: 10.15575/biodjati.v4i1.4216

${ }^{1}$ Laboratory of Plant Physiology, Faculty of Biology Universitas Gadjah Mada

${ }^{2}$ Faculty of Biology, Universitas Gadjah Mada

J1. Teknika Selatan, Sekip Utara, Yogyakarta 55281 telp/fax 0274580839

e-mail:

*1dwiumi@ugm.ac.id

wawien.oriz@gmail.com

*Corresponding author
Abstract. Curly red chili (Capsicum annum L.) is widely cultivated using inorganic fertilizers which causes high production costs. Chili is valued because of the level of spiciness. The level of spiciness of chili is determined by the level of capsaicin which is affected by nutrients in the growing media. The nutrient of the planting media can be fulfilled by degrading the growing media by microbes in organic fertilizer. One type of organic fertilizer containing degrading microbes is biofertilizer. Biofertilizer and biogas sludge is one of the organic fertilizers containing microbes and organic materials that are able to support nutrient levels of the planting medium. This study aimed to analyze growth parameters include chlorophyll content and measure capsaicin levels in curly red chili. Which given biofertilizer and biogas sludge in various dosage and determine the optimum dose of the fertilizer. The study was conducted at an agricultural demonstration plot in Wukirsari Village, Cangkringan, Sleman. The study design used RCBD (Randomized Complete Block Design), the data were analyzed by ANOVA (Analysis of Variance followed by Duncan's Multiple Distance Test (DMRT) at the 95\% confidence level. The highest growth parameters and capsaicin content were obtained on curly red chili plants which were given biogas sludge $36 \mathrm{~mL}+$ biofertilizer $10 \mathrm{~L} / \mathrm{ha}$. The application of biofertilizer and biogas sludge in various concentrations given has not been able to increase the average total chlorophyll content of curly red chili plants. Thus, it can be concluded that the most appropriate dose of curly red chili is $36 \mathrm{~mL}$ biogas sludge $+10 \mathrm{~L}$ bio fertilizer/ha.

Keywords: biofertilizer, biogas sludge, capsaicin, chili, growth

\section{Citation}

Siswanti, D. U. \& Lestari, M. F. (2019). Growth Rate and Capsaicin Level of Curly Red Chili (Capsicum annum L.) on Biofertilizer and Biogas Sludge Application. Jurnal Biodjati, 4(1), 126137

\section{INTRODUCTION}

Chili plants can grow well on soil with sufficient moisture content. Some regions in Indonesia, especially marginal areas have limitations, such us low or dry water levels.
Dry or too runny land will cause root function and growth to be disrupted. As a result, plant growth is also disturbed so that the flower and the fruit production will decline (Mubarokah, 2013). The requirements for growing chili plants in cultivating chili plants are influenced 


\section{JURNAL BIDDJATI}

http://journal.uinsgd.ac.id/index.php/biodjati

by climate factors which include sunlight intensity, rainfall, temperature and humidity, wind, altitude factors as well as soil conditions. The ideal temperature for chili cultivation is $24-28^{\circ} \mathrm{C}$. At certain temperatures such as $15^{\circ} \mathrm{C}$ or more than $32^{\circ} \mathrm{C}$, it will produce chili in the bad quality. Growth will be obstructed if the daily temperature in the cultivation area is too cold. According to Tjahjadi (1991), chili plants can grow in the dry season if sufficient irrigation is carried out regularly. Light intensity (irradiation) needed is a full irradiation. The desired rainfall is $800-2000$ $\mathrm{mm} /$ year with $80 \%$ plant humidity.

The height of the place for planting chili plants shoul be below 1,400 masl, such in the lowlands to the highlands. In highland areas, chili plants can grow but will not be optimal. Chili plants are very suitable to be planted on flat ground. Chili plants can also grow and adapt well to various types of soil, ranging from sandy soil to clay (Harpenas et al., 2010). The growth of chili plants will be optimum if planted in soil with a $\mathrm{pH}$ of 6-7 with loose, fertile, with sufficient humus contain (Sunaryono \& Rismunandar, 1984). Whereas, according to Tjahjadi (1991), chili plants can grow in soil conditions that contain essential nutrients such as elements $\mathrm{N}$ and K, and aren't in a waterlogged condition. The optimum growth of chili plants besides being supported by appropriate environmental factors also requires support from nutrients. Organic liquid fertilizer (biofertilizer) is very beneficial for plants that have limitations in absorbing solid fertilizers that are applied through the soil. Giving liquid organic fertilizer through the leaves will help overcome these limitations. The advantages of liquid organic fertilizer are the nutrients contained in it can be easily absorbed by plants. Maruapey (2015) said that the application of fertilizer through leaves, the nutrients from the fertilizer given will be ab- sorbed by the leaves through leaf stomata.

Cow urine can be used as biofertilizer. Fertilizing using fermented cow urine can increase vegetable production. Cow urine contains elements of $\mathrm{N}, \mathrm{P}, \mathrm{K}$ and $\mathrm{Ca}$ which are quite high and can increase the resistance of plants to disease attacks. Based on laboratory analysis of the urine properties before and after fermentation there were differences, the urine before fermentation has $\mathrm{pH}$ (7.2), $\mathrm{N}$ (1.1\%), P (0.5\%), K (1.5\%), Ca (1. 1\%) yellow and pungent odor, while urine after fermentation has $\mathrm{pH}(8.7), \mathrm{N}(2.7 \%), \mathrm{P}(2.4 \%)$ $\mathrm{K}(3.8 \%), \mathrm{Ca}(5.8 \%)$ black and smelly are reduced (Rizqiani et al., 2007). Lingga (2001) said that the urine of the cow contains a growth stimulant and in terms of its nutrient content, liquid manure from the urine of the cow has a higher nutrient content compared to its solid waste. Furthermore, Susetyo (2013) explained that cow urine also had a positive influence on vegetative growth of plants. Because the smell is unique, the urine of the cow can also prevent the arrival of various plant pests, so that the urine of the cow can also function as pest control for plants.

In addition to the use of cow urine, the use of biogas waste can also increase plant growth and development. Biogas is an alternative energy that is environmentally friendly. Biogas is produced in an anaerobic reactor with its energy components in the form of methane $\left(\mathrm{CH}_{4}\right)$, carbon dioxide $\left(\mathrm{CO}_{2}\right)$, nitrogen $\left(\mathrm{N}_{2}\right)$ and hydrogen sulfide $\left(\mathrm{H}_{2} \mathrm{~S}\right)$. Although biogas comes from waste treated in the reactor, biogas produces high energy, Biogas containing $75 \% \mathrm{CH}_{4}$ can produce energy as much as 26.9 MJ m-3 or $7.5 \mathrm{kWh} \mathrm{m-3}$. The main advantages of biogas energy production are to generate electricity and heat, reduce methane emissions and extra profits from commercialization with energy companies (Rosa et al., 2017). During the biogas production process 


\section{JURNAL BIDDJATI}

http://journal.uinsgd.ac.id/index.php/biodjati

as an energy source, biogas liquid waste will be produced in the form of biogas sludge. According to Wahyuni (2011), biogas sludge is a by-product of biogas in the form of mud, which contains a lot of nutrients which can be used as plant fertilizer. Nutrients that are high enough in biogas sludge can increase soil fertility by improving soil physical, chemical and biological properties. Biogas sludge has been anaerobically fermented so that it can be directly used to fertilize plants.

Based on the analysis of wet weight, the content in biogas waste liquid fertilizer or biogas sludge is organic C-48\%, N-total 2.9\%, $\mathrm{C} / \mathrm{N} 15.8 \%, \mathrm{P}_{2} \mathrm{O}_{5} 0.2 \%, \mathrm{~K}_{2} \mathrm{O} 0.3 \%$ (House Biogas Team, 2013). To obtain the maximum yield of organic fertilizer with raw materials for livestock manure, biofertilizer need to be added. Biofertilizer is an organic fertilizer containing nonsymbiotic microorganisms that are able to fix N (Nitrogen), mine P (Phosphorus) or function as a decomposer (Deshmukh et al., 2007). Biofertilizer has been applied in various researches in waste management and improving the quality of food production as a solution to increase land productivity and quality of crop production. Biofertilizer applications are needed by plant commodities which in their growth require essential nutrients such as $\mathrm{N}$ and $\mathrm{K}$. One of the horticultural commodities is curly red chili which has high economic value in Indonesia.

Siswanti et al. (2011) stated that the productivity of rice on Ngawen rainfed land in Gunung Kidul showed an increase after being given biofertilizer treatment. The study also used a biofertilizer dose of 10-15 L/ha as the optimum dose for rainfed land. According to Siswanti \& Rahmawati (2013), three rice varieties namely Situbagendit, Ciherang and Inpari 20 had optimal growth and an increase in soil nutrient content after the application of biofertilizer in paddy fields affected by Mer- api eruption in 2010. Siswanti \& Agustina (2014) stated that a combination of biofertilizer and vegetative decomposers have an effect on increasing leaf chlorophyll levels in two rice varieties, Menthik Wangi and Segreng. This combination also provides a good response to the increase in Nitrate Reductase Activity (NRA) on the leaves of the Segreng rice plant flag.

The use of organic fertilizer from biogas waste from cow manure (biogas sludge) has several benefits including increasing the formation of leaf chlorophyll, increasing plant vigor so that the plant becomes sturdy and increases plant resistance to drought (Rizqiani et al., 2007). Biogas sludge has characteristics that are free of pathogens and capable of killing disease-causing organisms in plants, can reduce the growth of weeds, as a good soil moisturizer because it can add topsoil and increase the water content in the soil (Handaka, 2012).

Although many previous research found out advantages provided by biofertilizer and biogas sludge, no one has combined the benefits of both. biofertilizer contains N, P and $\mathrm{K}$ fasting microbes and phytohormones, while biogas sludge contains nutrients ready for uptake for plants. This encourages researchers to examine whether the combination of both biofertilizer and biogas sludge can increase growth, chlorophyll levels and capsaicin levels of curly red chili plants. The purpose of this study was to analyze the growth and chlorophyll content of plants, measure the capsaicin content and find the optimum dose of biofertilizer biogas sludge combination for curly red chili plant that has the highest growth and capsaicin levels.

\section{MATERIALS AND METHODS}

Planting of curly red chili plants (Capsicum annum L.) was carried out in land area of 


\section{JURNAL BIDDJATI}

http://journal.uinsgd.ac.id/index.php/biodjati

$1000 \mathrm{~m}^{2}$ in Wukirsari village, Cangkringan, Sleman, Yogyakarta. The average environmental parameters were $\mathrm{pH} 7$, light intensity $461 \mathrm{lux}$ at $10 \mathrm{am}$, temperature $29^{\circ} \mathrm{C}$ at $10 \mathrm{am}$ and dry soil humidity (data were taken every week from $1^{\text {st }}$ until $8^{\text {th }}$ week after planting). Plant seeds are obtained from the Seed Hall of the Special Region of Yogyakarta (Balai Benih DIY).

The measurement of leaf chlorophyll levels (data was taken when the plant was 8 weeks after planting or before flowers appear) and testing of capsaicin levels (the data was taken when perfect red fruit) was carried out at the FALITMA (Joint Research Facility) of Faculty of Biology UGM and The Organic Chemistry Laboratory of the Faculty of Mathematics and Natural Sciences UGM. The study was conducted in April-September 2018. The growth parameters measured were plant height, leaf number and chlorophyll content using the Arnon Method (1949), and capsaicin levels that were measured using alkaloid extraction methods (Nugroho Method). The vegetative parameters were taken from $1^{\text {st }}$ week until $8^{\text {th }}$ week after planting (before the flower appear). The vegetative parameter observed including the height of plant, the number of leaves and the content of chlorophyll.

This study had a treatment factor including the use of different fertilizer doses consisting of 8 levels of treatment. The treatment design uses RCBD (Randomized Complete Block Design) with 5 replications. The following is the experimental design of the study. Treatment based on the purpose of research (Siswanti, 2010) :

1. Control (treat with NPK Fertilizer)

2. Biogas sludge $12 \mathrm{~mL}$

3. Biogas sludge $24 \mathrm{~mL}$

4. Biogas sludge $36 \mathrm{~mL}$

5. Biofertilizer $10 \mathrm{~L} / \mathrm{ha}$

6. Biogas sludge $12 \mathrm{~mL}+$ biofertilizer $10 \mathrm{~L} / \mathrm{ha}$
7. Biogas sludge $24 \mathrm{~mL}+$ biofertilizer $10 \mathrm{~L} / \mathrm{ha}$ 8. Biogas sludge $36 \mathrm{~mL}+$ biofertilizer $10 \mathrm{~L} / \mathrm{ha}$ Each treatment has 5 replications so that the total units were 45 experimental samples. Data were analyzed using ANOVA (Analysis of Variance), followed by DMRT test with a confidence level of $95 \%(\alpha=0.05)$. Data analysis was performed using SPSS software. $16^{\text {th }}$ edition.

\section{RESULTS AND DISCUSSION}

Measurement of growth parameters was carried out when curly red chili plants were at the vegetative phase. The vegetative phase of curly red chili plants in this study lasted for 8 weeks. The first aspect of vegetative growth measured was plant height. The measurement of plant height was carried out 7 days after the seedling of chili plants is planted and treated until the maximum vegetative phase of 8 weeks.

The average yield of curly red chili plants using biofertilizer and biogas sludge in various concentrations with NPK applications were not significantly different.

Whereas, the application of biofertilizer and biogas sludge at various concentrations was able to increase the average height of curly red chili plants eventhough it was not significantly different from the control (NPK treatment only). Curly red chili plants with the application of $36 \mathrm{~mL}$ biogas sludge $+10 \mathrm{~L}$ biofertilizer/ha had the highest average plant height compared to other doses of biogas sludge and biofertilizer as well as NPK application (control). The lowest average plant height was found in the application of $12 \mathrm{~mL}$ biogas sludge and $10 \mathrm{~L} /$ ha biofertilizer. There was a significant difference between the mean plant height from plant that was given $36 \mathrm{~mL}$ biogas sludge + biofertilizer $10 \mathrm{~L} /$ ha with the average yield of plants both fertilizer appli- 


\section{JURNAL BIDDJATI}

http://journal.uinsgd.ac.id/index.php/biodjati

cation with $36 \mathrm{~mL}$ biogas sludge and biogas sludge $12 \mathrm{~mL}$ + biofertilizer $10 \mathrm{~L} /$ ha (Table 1 ).

When compared with the control, the application of $12 \mathrm{~mL}$ biogas sludge + biofertilizer $10 \mathrm{~L} / \mathrm{ha}$; and biogas sludge $36 \mathrm{~mL}+$ biofertilizer $10 \mathrm{~L} /$ ha increased the average plant height. The highest concentration of biofertilizer and biogas sludge, namely $36 \mathrm{~mL}$ biogas sludge + biofertilizer $10 \mathrm{~L} / \mathrm{ha}$, had the highest plant height compared to other doses and NPK application (control). In the 24 $\mathrm{mL}$ biogas sludge application; $36 \mathrm{~mL}$ sludge; sludge biogas $12 \mathrm{~mL}+$ biofertilizer $10 \mathrm{~L} / \mathrm{ha}$; and sludge biogas $24 \mathrm{~mL}+$ biofertilizer $10 \mathrm{~L} /$ ha tend to reduce the average height of curly red chili plant. Based on statistical analysis using DMRT with a confidence level of $95 \%$ $(\alpha=0.05)$, it was not significantly different for all fertilizer application doses compared to NPK applications (controls). The absence of significant differences in the application of biofertilizer and biogas sludge can be attributed to the fact that the dosage has not been able to play an optimal role in increasing the plant height so that it produces the same height as the control or different from the control but the difference is not significant. Biofertilizer has no effect on plant height because it contains $\mathrm{N}$-fixing microbes, decomposers $\mathrm{P}$ and $\mathrm{K}$, and hormones, but does not provide nutrients. While the tethering and reshaping process of fertilizer takes time, in contrast to inorganic fertilizers that provide available nutrients (Siswanti, 2010)

The second aspect of vegetative growth measured is the number of leaves. The number of leaves calculated is the one which have opened perfectly. This measurement is carried out 7 days after the seedling of chili plants. The plants were then planted and treated until the maximum vegetative phase is 8 .

The rate of addition of curly red chili plants leaves has a positive correlation, ie the growth rate increases in proportion to the age of the plant. It is known that the highest number of leaves is in plants with the application of $36 \mathrm{~mL}$ biogas sludge $+10 \mathrm{~L}$ biofertilizer/ ha while the number of leaves is the least in plants with $36 \mathrm{~mL}$ biogas sludge application only.

Table 1. Effect of biofertilizer and biogas sludge application on plant height.

\begin{tabular}{|c|c|c|}
\hline No & Treatment & Plant Height $(\mathrm{cm})$ \\
\hline 1 & Biogas sludge $12 \mathrm{~mL}$ & $65.8 \pm 10.7^{\mathrm{ab}}$ \\
\hline 2 & Biogas sludge $24 \mathrm{~mL}$ & $60.6 \pm 5.5^{\mathrm{ab}}$ \\
\hline 3 & Biogas sludge $36 \mathrm{~mL}$ & $56.2 \pm 9.6^{\mathrm{a}}$ \\
\hline 4 & Biofertilizer $10 \mathrm{~L} / \mathrm{ha}$ & $63.2 \pm 10.5^{\mathrm{ab}}$ \\
\hline 5 & Biogas sludge $12 \mathrm{~mL}+$ biofertilizer $10 \mathrm{~L} / \mathrm{ha}$ & $53.2 \pm 6.5^{\mathrm{a}}$ \\
\hline 6 & Biogas sludge $24 \mathrm{~mL}+$ biofertilizer $10 \mathrm{~L} / \mathrm{ha}$ & $60.8 \pm 12.6^{\mathrm{ab}}$ \\
\hline 7 & Biogas sludge $36 \mathrm{~mL}+$ biofertilizer $10 \mathrm{~L} / \mathrm{ha}$ & $72.2 \pm 3.7^{\mathrm{b}}$ \\
\hline 8 & Control (NPK fertilizer) & $62.0 \pm 6.8^{\mathrm{ab}}$ \\
\hline
\end{tabular}




\section{JURNAL BIDDJATI}

http://journal.uinsgd.ac.id/index.php/biodjati

There were differences in the results of the average number of leaves of plants using biofertilizer and biogas sludge in various concentrations with controls, although that were not significantly different (Table 2).

The application of biofertilizer and biogas sludge at various concentrations was able to increase the average number of leaves in curly red chili plants with a considerable amount compared to the control. The curly red chili plants have the highest average number of leaves with the application of $36 \mathrm{~mL}$ biogas sludge + biofertilizer $10 \mathrm{~L} /$ ha as well as the application of $10 \mathrm{~L} /$ ha biofertilizer only, while the average number of leaves is the least in the $36 \mathrm{~mL}$ biogas sludge application. Based on statistical analysis using a confidence level of $95 \%(\alpha=0.05)$, there was a significant difference between the average number of leaves in curly red chili plant application after treatment with $36 \mathrm{~mL}$ biogas sludge + biofertilizer $10 \mathrm{~L} /$ ha compared with the average number of leaves of both applications of fertilizer with a dose $36 \mathrm{~mL}$ biogas sludge and $12 \mathrm{~mL}$ biogas sludge $+10 \mathrm{~L} /$ ha biofertilizer. Then, there was a significant difference between the average number of leaves from the application of biofertilizer $10 \mathrm{~L} / \mathrm{ha}$ with the average number of leaves of both application fertilizer with 36 $\mathrm{mL}$ biogas sludge, $12 \mathrm{~mL}$ sludge + bio fertilizer $10 \mathrm{~L} / \mathrm{ha}$. This showed that the combination application of biofertilizer and biogas sludge with a dose of $36 \mathrm{~mL}$ sludge biogas + biofertilizer $10 \mathrm{~L} / \mathrm{ha}$ and a biofertilizer dose of $10 \mathrm{~L} /$ ha only were more effective in increasing the number of leaves in curly red chili plants compared to $36 \mathrm{~mL}$ sludge biogas application only.

When compared with controls, the application of biofertilizer and biogas sludge with $12 \mathrm{~mL}$ sludge dose; $24 \mathrm{~mL}$ biogas sludge; biofertilizer $10 \mathrm{~L} / \mathrm{ha}$; biogas sludge $24 \mathrm{~mL}+$ biofertilizer $10 \mathrm{~L} / \mathrm{ha}$; as well as biogas sludge $36 \mathrm{~mL}+$ biofertilizer $10 \mathrm{~L} /$ ha tend to increase the average number of leaves of curly red chili plants. The application of $36 \mathrm{~mL}$ sludge +10 $\mathrm{L} /$ ha biofertilizer on curly red chili plants had the highest number of leaf plants compared to other doses and controls. Based on the research, there was no significant difference in all doses of fertilizer application compared to the control on the number of curly red chili plant leaves.

Based on the description, it can be seen that the application of $36 \mathrm{~mL}$ biogas sludge and $10 \mathrm{~L}$ biofertilizer/ha increased the average number of curly red chili plant leaves even though statistical analysis did not provide a real difference. The higher concentrations of biofertilizer and biogas sludge given tend to be able to increase the average number of leaves of curly red chili plants. This can be seen in the application of the highest dosage in the form of $36 \mathrm{~mL}$ biogas sludge $+10 \mathrm{~L}$ biofertilizer/ha, indicating the highest number of leaves formed compared to the application of fertilizers with other doses and or NPK application (control).

The application of $36 \mathrm{~mL}$ biogas sludge + biofertilizer $10 \mathrm{~L} /$ ha was the optimum dose to increase the number of leaves of curly red chili plants. This can happen because there is a balance between biogas sludge and biofertilizer so that the absorption by plant roots becomes more optimum. If the dosage of fertilizer given is too high, it might cause absorption of nutrients by the roots can not optimal because of the absorption of nutrients by microbes contained in fertilizers. In addition, the high nutrient content in biogas sludge and biofertilizer can improve the quality of curly red chili plants to produce more leaves. The nitrogen element contained in biogas sludge fertilizer plays a role in leaf, growth the leaves of the plant become wider with greener leaf colors (Sperling, 2007).

The application of biofertilizer $10 \mathrm{~L} / \mathrm{ha}$ 


\section{JURNAL BIDDJATI}

http://journal.uinsgd.ac.id/index.php/biodjati

on curly red chili plants also showed a higher number of leaves than the control, but did not exceed the number of leaves in the treatment with $36 \mathrm{~mL}$ biogas sludge $+10 \mathrm{~L} / \mathrm{ha}$ biofertilizer. The treatment of a biofertilizer dose of $10 \mathrm{~L} / \mathrm{ha}$, also provides the optimum dose to increase the number of leaves of curly red chili plants. This can happen due to the fact that biofertilizer from cow urine is applied through fertilization spray on the leaves of plants, so nutrients in biofertilizer from cow urine can be easily absorbed by plants through leaf stomata and directly used in plant metabolism. The process of absorption of nutrients by plants is faster through leaves than through roots, so that the application of biofertilizer $10 \mathrm{~L} /$ ha can increase plant growth such as the number of leaves. Stomata acts as an evaporation tool and an absorption device. Plants absorb $\mathrm{CO}_{2}$ and other elements from the environment through the stomata. The mechanism of opening and closing of the stomata depends on turgor pressure, carbohydrate concentration, light and ABA hormone (Fahn, 1982) and amylum hydrolysis of the stomata guard cells (Wilkins, 1978). Giving fertilizer through the surface the leaves will give optimal results (Patima, et al., 2014), Lingga (2001) stated that application of fertilizer by spraying on the leaf surface provides several advantages compared passing land, because of the nutrients given can be absorbed by the leaves faster than roots.

Table 2. Effect of biofertilizer and biogas sludge application on the number of leaves.

\begin{tabular}{llc}
\hline No & \multicolumn{1}{c}{ Treatment } & Number of Leaves ${ }^{-}$ \\
\hline 1 & Biogas sludge 12 mL & $52.6 \pm 22.4^{\mathrm{abc}}$ \\
2 & Biogas sludge 24 mL & $51.2 \pm 14.3^{\mathrm{abc}}$ \\
3 & Biogas sludge 36 mL & $36.2 \pm 15.8^{\mathrm{a}}$ \\
4 & Biofertilizer 10 L/ha & $67.4 \pm 25.7^{\mathrm{bc}}$ \\
5 & Biogas sludge 12 mL + biofertilizer 10 L/ha & $41.6 \pm 11.1^{\mathrm{ab}}$ \\
6 & Biogas sludge 24 mL + biofertilizer 10 L/ha & $52.2 \pm 33.4^{\mathrm{abc}}$ \\
7 & Biogas sludge 36 mL + biofertilizer 10 L/ha & $74.6 \pm 20.0^{\mathrm{c}}$ \\
8 & Control (NPK fertilizerr) & $47.6 \pm 6.8^{\mathrm{abc}}$ \\
\hline
\end{tabular}

Chlorophyll content of the leaves of curly red chili plants showed varying results at each given dose of fertilizer (Figure 1). Plants with treatment tended to have lower levels of chlorophyll than chlorophyll levels in the control. It was known that the highest chlorophyll content of leaves is in plants with NPK application (control) while the least chlorophyll content found in leaves is of plants with the application of $36 \mathrm{~mL}$ biogas sludge both levels of chlorophyll a, chlorophyll $\mathrm{b}$ and to- tal chlorophyll. Chlorophyll a level from all applications of biofertilizer and biogas sludge and control was higher than chlorophyll $b$ levels. This is likely to occur because some chlorophyll is still at the stage of chlorophyll a (seen in the chlorophyll a content greater than chlorophyll b) and has not yet become chlorophyll $\mathrm{b}$, because chlorophyll $\mathrm{a}$ is a precursor of chlorophyll b (Robinson, 1980). Chlorophyll $\mathrm{b}$ is chlorophyll which acts as an antenna that collects light to then be trans- 


\section{JURNAL BIDDJATI}

http://journal.uinsgd.ac.id/index.php/biodjati

ferred to the center reaction. The center reaction is composed of chlorophyll a. Light energy will be converted into chemical energy in the center reaction which can then be used for the reduction process in photosynthesis (Taiz \& Zieger, 1991).

The average total chlorophyll levels at all doses of biofertilizer and biogas sludge treatment have significantly different results with the average total chlorophyll levels in control. Curly red chili plants control treatment with NPK application had the highest total chlorophyll content of the leaves while the application of $36 \mathrm{~mL}$ sludge biogas had the lowest average total leaf chlorophyll content (Figure 1)

Based on the description, it can be seen that the application of biofertilizer and biogas sludge in various concentrations given has not

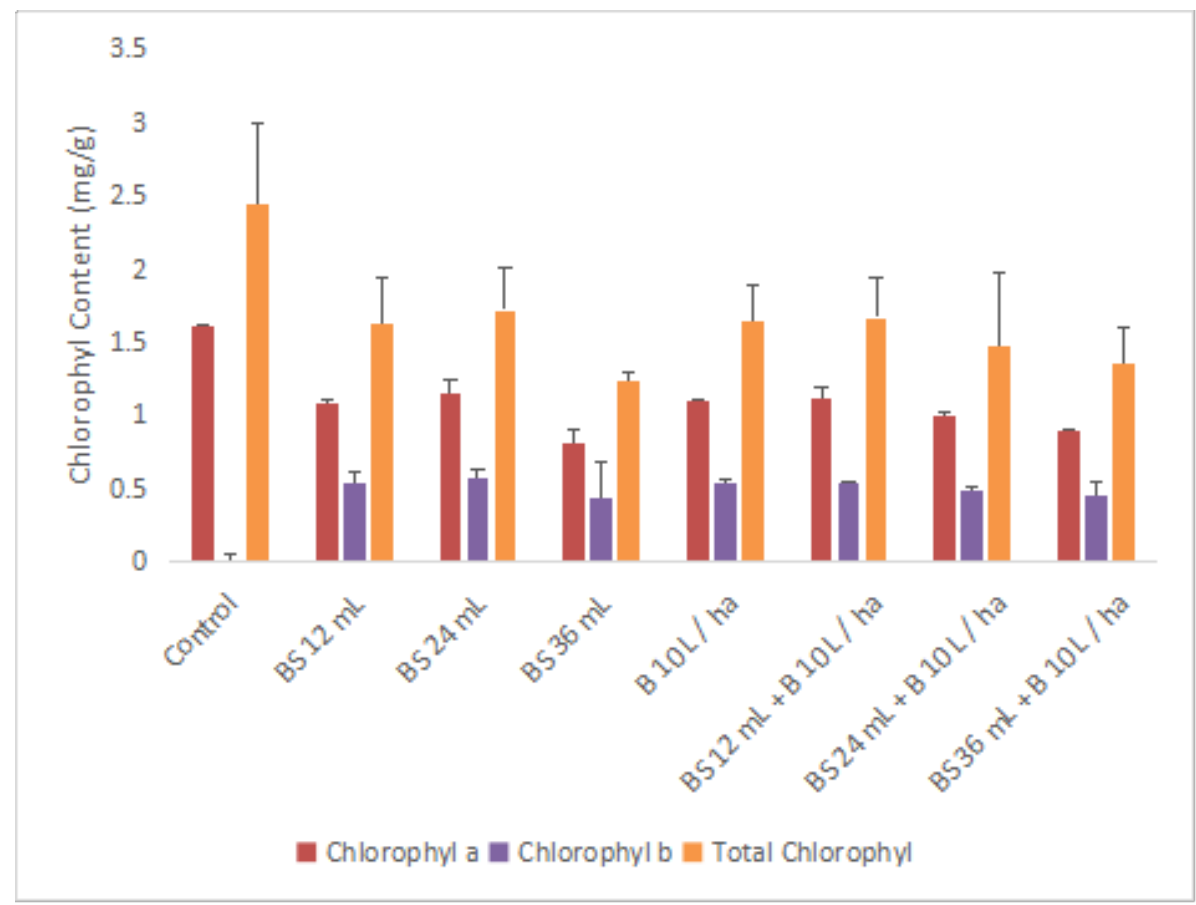

Figure 1. Levels of chlorophyll a, chlorophyll b, and total chlorophyll in the of leaves of curly red chili plants (Capsicum annum L.) as a result of biofertilizer and biogas sludge biogas at 8 th week after planting. BS : Biogas Sludge, B : Biofertilizer.

been able to increase the average total of chlorophyll content in curly red chili plants. These results might be happened due to abundant nutrients and are sufficient in plants with the application of biofertilizer and biogas sludge which is capable of accelerating the vegetative growth of curly red chili plants so that the plants have entered the generative phase. When curly red chili plants with the application of biofertilizer and biogas sludge have entered the generative phase, the state of the control plants with low nutrient availability causes the plants to be in the vegetative phase at the same planting age. According to Mengel and Ernest (2012), the low nutrient available for plants can cause growth inhibition in these plants. In its generative phase, curly red chili plants optimize nutrients from biofertilizers and biogas sludge which are absorbed to form chili fruit and grain seeds on chili fruit, so that these nutrients are not fully used for growth and increase chlorophyll levels in the leaves. 


\section{JURNAL BIDDJATI}

http://journal.uinsgd.ac.id/index.php/biodjati

In control plants, optimum nutrients absorbed by plants for growth and increase chlorophyll levels in the leaves. So, it can be seen from the results of the total chlorophyll levels of curly red chili plants in the control having a higher total chlorophyll level compared to all curly red chili plants with the application of biofertilizer and biogas sludge. In control plants, NPK fertilizer is loaded with N content. Nitogen fertilization will increase the chlorophyll content, because $\mathrm{N}$ is the basic component of chlorophyll (Lawlor, 1987).

Table 3. Effect of biofertilizer and biogas sludge treatment on total chlorophyll levels.

\begin{tabular}{llc}
\hline No & \multicolumn{1}{c}{ Treatment } & $\begin{array}{c}\text { Chlorophyll Content } \\
(\mathrm{mg} / \mathrm{g})\end{array}$ \\
\hline 1 & Biogas sludge $12 \mathrm{~mL}$ & $1.6 \pm 0.3^{\mathrm{a}}$ \\
2 & Biogas sludge $24 \mathrm{~mL}$ & $1.7 \pm 0.2^{\mathrm{a}}$ \\
3 & Biogas sludge $36 \mathrm{~mL}$ & $1.2 \pm 0.1^{\mathrm{a}}$ \\
4 & Biofertilizer 10 L/ha & $1.6 \pm 0.3^{\mathrm{a}}$ \\
5 & Biogas sludge $12 \mathrm{~mL}+$ Biofertilizer 10 L/ha & $1.7 \pm 0.3^{\mathrm{a}}$ \\
6 & Biogas sludge 24 mL + Biofertilizer 10 L/ha & $1.5 \pm 0.5^{\mathrm{a}}$ \\
7 & Biogas sludge 36 mL + biofertilizer 10 L/ha & $1.4 \pm 0.2^{\mathrm{a}}$ \\
8 & Control (NPK fertilizer) & $2.4 \pm 0.6^{\mathrm{b}}$ \\
\hline
\end{tabular}

The measurement of capsaicin levels was carried out at the maximum vegetative phase of the curly red chili plant which was at the $8^{\text {th }}$ week (Figure 2).

Capsaicin levels of curly red chili fruit showed mixed results at each given dose of fertilizer (Figure 2). It can be seen that the highest capsaicin levels were in plants with the application of $36 \mathrm{~mL}$ biogas sludge $+10 \mathrm{~L}$ biofertilizer/ha while the least capsaicin levels were found in plants with $36 \mathrm{~mL}$ biogas sludge application, $12 \mathrm{~mL}$ biogas sludge + $10 \mathrm{~L} /$ ha biofertilizer, as well as $24 \mathrm{~mL}$ biogas sludge +10 L biofertilizer. When compared with controls, plants with application of biofertilizer $10 \mathrm{~L} / \mathrm{ha}$ and application of $36 \mathrm{~mL}$ biogas sludge $+10 \mathrm{~L} /$ ha biofertilizer were able to increase capsaicin levels in curly red chili plants while the application of biofertilizer and biogas sludge with other doses tended to reduce capsaicin levels.

It is known that the most optimal level of capsaicin was found in the treatment of
$36 \mathrm{~mL}$ biogas sludge $+10 \mathrm{~L} / \mathrm{ha}$ bio fertilizer which was the highest dose. This indicates that an increase in the dosage of application of biofertilizer and biogas sludge in susceptible plant tolerance can increase capsaicin levels in curly red chili fruit. Based on the analysis of wet weight, the content in biogas waste liquid fertilizer is organic $\mathrm{C}-48 \%$, N-total $2.9 \%$, $\mathrm{C} / \mathrm{N} 15.8 \%, \mathrm{P}_{2} \mathrm{O}_{5} 0.2 \%, \mathrm{~K}_{2} \mathrm{O} \quad 0.3 \%$ (House Biogas Team, 2013). The content of biogas sludge which is rich in carbon and nitrogen makes the vegetative and generative growth of curly red chili plants balanced and faster, so that they can form more secondary metabolites compared to chili in the control group. According to Lingga (2001), increasing the dose of nitrogen fertilizer will increase the total content of alkaloids.

Based on the results of the research on the physiological response of the curly chili plant by biofertilizer and biogas sludge application, some conclusions can be drawn as follows the growth of curly red chili plants 


\section{JURNAL BIDDJATI}

http://journal.uinsgd.ac.id/index.php/biodjati

is best in the application of $36 \mathrm{~mL}$ biogas sludge $+10 \mathrm{~L} /$ ha biofertilizer. Curly red chili plants with various concentrations of biofertilizer and biogas sludge have lower chlo- rophyll content compared to controls. The application of $36 \mathrm{~mL}$ biogas sludge $+10 \mathrm{~L} /$ ha biofertilizer on curly red chili plants has resulted in the highest capsaicin levels.

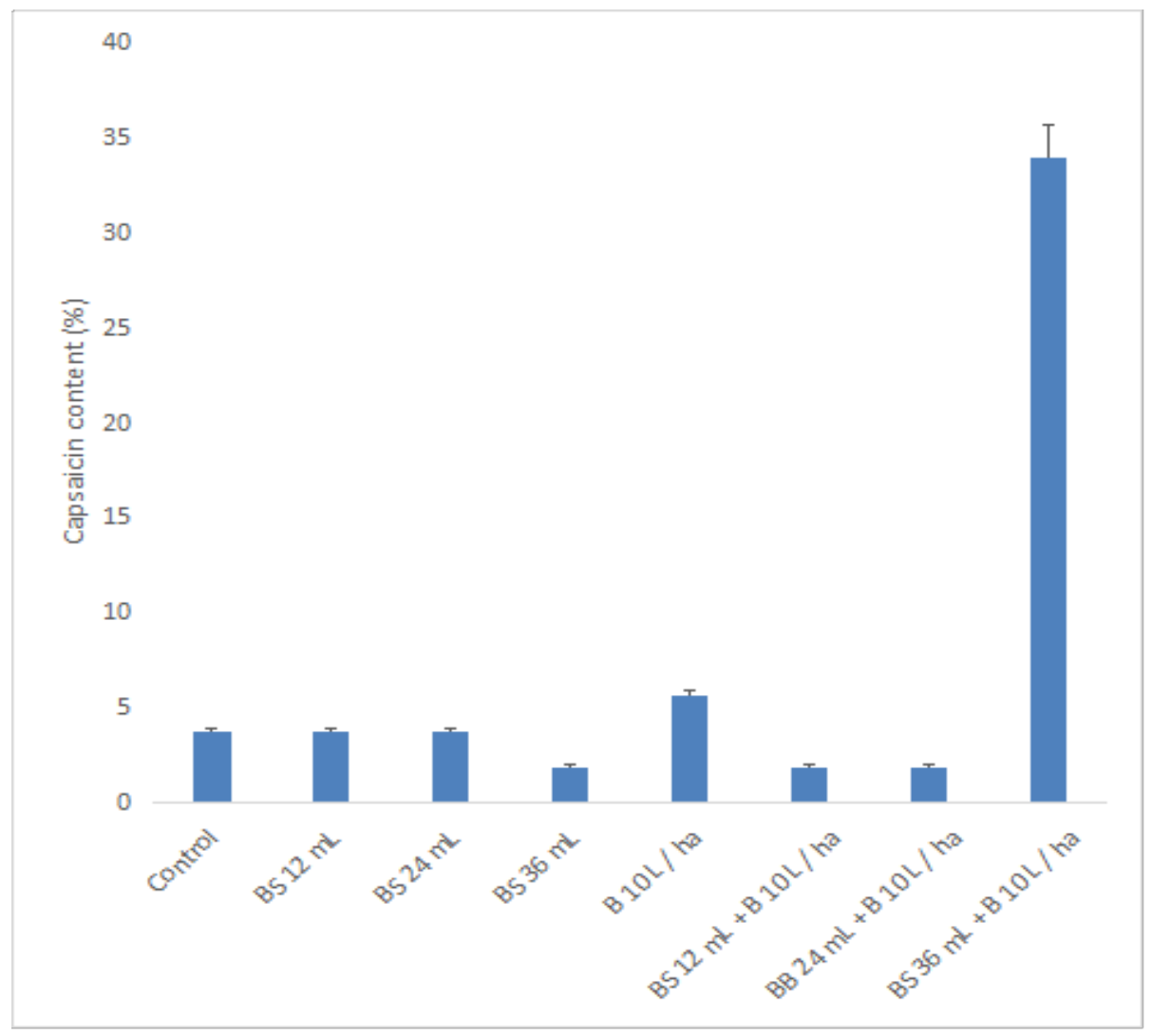

Figure 2. Capsaicin levels of curly red chili fruit (Capsicum annum L.) as a result of biofertilizer and biogas sludge application at 8 th week after planting. BS : Biogas Sludge, B : Biofertilizer.

\section{ACKNOWLEDGMENTS}

Thanks to Final Assignment Recognition Grant Universitas Gadjah Mada, Research Institute and Community Service (LPPM) Universitas Gadjah Mada and Faculty of Biology Universitas Gadjah Mada have funded this research and publication as well as Utaminingsih, who help read the capsaicin data.

\section{REFERENCES}

Arnon, D. I. (1949). Copper Enzyme in Isolated Chloroplast Polyphenoloxidase in Beta vulgaris. Plant Physiology, 24, 1-15.

Deshmukh, A. A., Gajare, K. A. \& Pillai, M. M. (2007). Protective Effects of Ethanolic Extract of Lettuce (Lactuva sativa L.) on Neuronal Lupifisino Genesis in D Galactose Induced Ageing Accelerat- 


\section{JURNAL BIDDJATI}

http://journal.uinsgd.ac.id/index.php/biodjati

ed Albino mice. J. Herb. Med. Toxicol., 1(2), 43-47.

Fahn, A. (1982). Anatomi Tumbuhan. Transletter: A. Sudiarto, T. Kusumaningrat, M. Natasaputra and H. Akmal. Yogyakarta: Gadjah Mada University Press.

Handaka, W. (2012). Bio-slurry Hasil Proses Biogas untuk Pertanian dan Perkebunan Ramah Lingkungan. Retrieved from http://bengkulu2green.wordpress.com/ author/bengkulu2green/

Harpenas, Asep. \& Dermawan, R. (2010). Budidaya Cabai Unggul. Jakarta: Penebar Swadaya.

House Biogas Team. (2013). Pedoman, Pengguna, Pengawas Pengelolaan dan Pemafaatan Bio Slurry. Jakarta: Yayasan Rumah Energi.

Lingga, P. (2001). Petunjuk Penggunaan Pupuk. Jakarta: Penebar Swadaya.

Lowlor, D. W. (1987). Photosynthesis Metabolism Control and Physiology. England: Longman Group Lmt.

Maruapey, A. (2015). Pengaruh Pupuk Organik Limbah Biogas Cair Kotoran Sapi Terhadap Pertumbuhan dan Produksi Tanaman Jagung Manis (Zea Mays Saccharata Sturt). Jurnal Agroforestri, 10(3), 191-200.

Mengel, K. \& Ernest, A. K. (2012). Principles of Plant Nutrition. Giessen: Springer Science \& Business Media.

Mubarokah, L. L. (2013). Respon Karakter Morfo-fisiologis dan Akumulasi Bioaktif Antosianin Tanaman Bayam Merah (Alternanthera amoena Voss) terhadap Cekaman Kekeringan. Skripsi. UIN Sunan Kalijaga Yogyakarta

Nugroho, L. H., Hastuti, H. T., Astutiningsih, T. \& Sumardi, I. (2006). Karakteristik Cabai rawit (Capsicum frutescens L.) yang Ditumbuhkan Secara Hidroponik. Berkala Ilmiah Biologi, 5(1), 13-21.
Patima, S., Samudin, S. \& Yusuf, R. (2014). Pertumbuhan dan Hasil Tanaman Sawi (Brassica juncea L.) yang Tumbuh pada Berbagai Media Tanam dan Pemberian Pupuk Organik Cair. J. Agroland, 21(2), 86-94.

Rizqiani, N. F. Ambarwati, E. \& Yuwono, N. W. (2007). Pengaruh Dosis dan Frekuensi Pemberian Pupuk Organik Cair Terhadap Pertumbuhan dan Hasil Buncis (Phaseolus vulgaris L.) Dataran Rendah. Jurnal Ilmu Tanah dan Lingkungan, 7, 43-53.

Robinson, T. (1980). The Organic Constituents of Higher Plants. 4th ed. North Amherst, Mass: Cordus Press.

Rosa, A.P., Chernicharo, C.A. L., Lobato, L. C. S., Padilha, R. F. \& Borges, J. M. (2017). Assessing The Potential of Renewable Energy Sources (Biogas and Sludge) in A Full-Scale UASB-Based Treatment Plant. Renewable Energy, 30, 1-6.

Siswanti, D. U. 2010. Plant Response and Nitrate Reductase Activity in Vivo on Rice (Oryza sativa L.) Cultivars IR-64 to Biofertilizer Application and Drought. Thesis. Universitas Gadjah Mada.

Siswanti, D. U. D., Rahmawati, Maryani \& Hartiko, H. (2011). Innovation Rice Cultivation with Bio Fertilizer to Increase Productivity of Three Rice Cultivars (Oryza sativa L.) In Rainfed Land Beji Village, Ngawen, Gunung Kidul, Yogyakarta, Indonesia. Oral Presentation. International Conference of Biological Science. Universitas Gadjah Mada. Siswanti, D. U. \& Rahmawati, D. (2013). Plant Growth of Three Cultivars of Rice (Oryza sativa L.) against Bio Fertilizer Application and Agriculture Soil Condition Post Merapi Eruption 2010. Journal Biogenesis, 1(2), 110-115.

Siswanti, D. U. \& Agustin, R.V. (2014). Phys- 


\section{JURNAL BI@DJATI}

http://journal.uinsgd.ac.id/index.php/biodjati

iological Response of Rice (Oryza sativa L.) "Segreng" and "Menthik Wangi" Against Bio Fertilizer Application and Decomposers. Journal Biogenesis, 2(2), 89-93.

Sperling, M. V. (2007). Activated Sludge and Aerobic Biofilm Reactors. New York: IWA Publishing.

Sunaryono, Handro dan Rismunandar. (1984). Kunci Bercocok Tanam Sayuran-Sayuran Penting di Indonesia. Bandung: Sinar Baru.

Susetyo, N. A. 2013. Pemanfaatan Urin Sapi sebagai POC (Pupuk Organik Cair) dengan Penambahan Akar Bambu Melalui Proses Fermentasi Dengan Waktu yang Berbeda. Skripsi. Fakultas Keguruan dan Ilmu Pendidikan, Universitas Muhammadiyah Surakarta.
Taiz. L. \& Zeiger, E. (1991). Plant Physiology. 3th Edition Sinauer Association Sunderland.

Tjahjadi, N. (1991). Bertanam Cabai. Yogyakarta: Kanisius.

Wahyuni, S. (2011). Menghasilkan Biogas dari Aneka Limbah. Edisi Pertama. Jakarta: PT Agro Media Pustaka.

Wilkins, S. (1981). Fundamental of Rice Crop Science. IRRI. Los Banos. Laguma, Philippines. 